\title{
A casa e a câmera: em tempo de compartilhar - análise do narrador de Santiago, de João Salles
}

\author{
Eduardo Brandão Pinto*
}

\begin{abstract}
Resumo: Trata-se de uma crítica de Santiago, de 2007, filme de João Moreira Salles, que tem por tema sua tentativa fracassada de realizar um documentário sobre seu ex-mordomo, Santiago, em 1992. Proponho uma análise do narrador a fim de interpretar a tomada de consciência do sujeito autoral da obra sobre a desigualdade de poder entre o diretor e o objeto. Tentando uma abordagem que se aproxime da sensibilidade humana requisitada pela obra, compreendo que o filme desenvolve a expressão de uma tragédia epistêmica e social que provoca o dilaceramento da percepção subjetiva, e cuja existência já estava ancorada na relação patrão/empregado sob a qual o cineasta e seu personagem se conheceram e travaram afeto.
\end{abstract}

Palavras-chave: crítica de arte, Sociologia do cinema, documentário, narrador, sujeito.

And all these words They mean nothing at all Just a cruel remedy A strange tragedy of what will be

(Da canção "Lonely Carousel”, de Beth Gibbons)

No último plano do filme, vemos o personagem-título dançando; mas dançando não esta música, pois esta - já nos havia advertido o narrador, cuja voz fala em nome do diretor - só vim a conhecer mais tarde.

\section{Às voltas com o tempo fissurado: tentativa de narrar}

Minuto 1. Uma fotografia envolta por uma moldura está disposta solitária sobre uma mesinha, vista em plano médio. 0 próprio plano que vemos, com o preto-e-branco que nos acompanhará por todo o filme (quebrado apenas na exibição de trechos de uma filmagem familiar da infância do narrador e de um filme com Fred Astaire e Cyd Charrisse), sugere uma outra fotografia: por trás da mesinha, podemos ver um estilizado jogo de luzes e sombras que nos indica estarmos diante de uma

${ }^{*}$ Graduando em Audiovisual - UFF. 
construção visual elaborada, em que são sobrepostas duas fotos: uma está sendo filmada e a outra é a própria filmagem. Podemos depreender a existência de três tempos distintos, articulados nessa construção: um primeiro tempo, mais distante e remoto, a respeito do qual "fala" a fotografia sobre a mesa, isto é, quando ela foi tirada; um segundo tempo, intermediário, sobre o qual "fala" a fotografia que é o próprio plano cinematográfico, compreendendo o instante em que a filmagem foi realizada e que o retrato sobre a mesinha era observado; e um terceiro tempo dado no presente em que é fruída a edição da fotografia do plano cinematográfico.

Segue-se a este plano outros dois, semelhantes, em que são mostradas outras duas fotografias emolduradas. Em todos os três, a câmera descreve um lento travelling para a frente, o que nos possibilita ver com mais detalhe o conteúdo das fotos. Todas elas mostram interiores de um prédio, vazios e com poucos móveis. Essa semelhança nas formas entre as fotografias - a que está dentro do plano e a que é o próprio plano - nos indica, já de início, um vínculo entre os tempos, distintos, em que ambas foram arquitetadas e clicadas.

A construção do filme como representações sobre o tempo passado é indicada nas primeiras palavras que ouvimos de uma voz-off ${ }^{1}$ : “Há treze anos [...]”. Enquanto informa sobre estar retomando um projeto malfadado de um filme, o narrador, cumpliciado com as imagens, embrenha-se numa imersão metalinguística em que desnuda as opções estéticas manejadas na construção daqueles três planos iniciais. São mostrados os três conteúdos dos retratos que vimos emoldurados, agora exibidos como objeto direto da filmagem, e não intermediados por uma segunda câmera. Os três tempos anteriormente construídos se recompõem em apenas dois, pois o tempo do retrato sobre a mesinha e o tempo do plano cinematográfico passam a ser os mesmos. A tessitura temporal anterior é sugestivamente revelada como uma construção artificial, que, assim como um dia foi montada, pode um dia ser desmontada. É como se assistisse aos bastidores do momento em que foi dado o clique na câmera, a partir de um ponto de vista que deixa ver alguma coisa que antes ficava fora de quadro. Num dos planos, um membro da equipe aparece com uma câmera na mão.

\footnotetext{
${ }^{1}$ Uso o termo voz-off no sentido amplo, de voz cujas falas são ouvidas pelo espectador sem que esteja em quadro a imagem dono da boca que as pronuncia, muito embora algumas vezes tem-se preferido o termo voz-over para os casos em que o personagem emite suas palavras estando em outro espaço ou tempo ficcionais (como é o caso do narrador de Santiago), deixando a expressão voz-off apenas para situações em que o personagem está efetivamente de corpo presente em cena, mas cujo corpo fica omitido pelos limites do enquadramento.
} 
Entre as falas do narrador, somos informados do enredo deste documentário: em 1992, o diretor que levou a cabo o presente projeto, e que ficcionalmente é o mesmo indivíduo que o espectador ouve pronunciar-se na primeira pessoa nas palavras da voz-off, realizava um filme tendo por personagem o antigo mordomo da casa dos pais, Santiago. 0 material bruto, herdado do projeto abandonado, é composto por cinco dias de entrevista com o personagem no pequeno apartamento onde ele, já velho, morava, acrescido de tomadas atuais da casa, desabitada, onde diretor e personagem moraram num passado mais distante; além dessas, conta com várias cenas em estúdio - um trem elétrico em miniatura circulando sobre o trilho, duas rosas brancas, um boxeador treinando, duas sacolas plásticas que, após serem manejadas por um par de mãos, são soltas para voarem ao vento (esta última, não em estúdio), e outras tomadas que o narrador diz existir, mas que jamais nos são mostradas. Por motivo que em momento algum nos é indicado com clareza, o projeto foi deixado para trás, sendo retomado em 2005, resultando numa reflexão sobre os recursos audiovisuais usados, ou projetados para usar, pelo diretor de 1992 a fim de dar expressão ao personagem e ao seu passado.

A forma comum a toda narração pressupõe a construção de dois tempos narrativos colocados em contato: um tempo passado, cujos episódios fornecem a matéria-prima a ser transformada pelo narrador em expressão; e um tempo presente, quando o narrador de fato narra, articulando os insumos oferecidos pelo tempo passado, e alguém frui o resultado dessa narração. Nesse segundo momento, criam-se significados e juízos sobre aquele tempo a respeito do qual se fala, operação feita em partilha por narrador e fruidor. A narração em Santiago é apresentada, logo de saída, como resultante de uma frustração. 0 insucesso do narrador-personagem na composição do filme de 1992 é experiência que agora se transforma em matéria bruta, pronta a abastecer uma nova tentativa de narrar. Porém, fala-se de uma experiência passada que já se propunha a tomar por objeto outras experiências passadas. Trata-se de uma narração sobre outra narração, um mais-narrar, que produzirá a substituição do objeto principal sobre o qual se fala: em vez de ter como ponto de chegada o passado longínquo - internalizado pelos dois indivíduos, João Salles e Santiago, na forma de memória -, a narração se volta para si mesma, coloca-se em espaços distintos do percurso discursivo; ela é, ao mesmo tempo, forma e assunto, ponto de partida e ponto de chegada, processo e resultado.

Pode-se dizer que a estrutura temporal de Santiago está dividia em três eixos, instaurados na inserção de um tempo intermediário aos dois extremos da narração. 
Para facilitar as referências ao longo deste texto, irei nomeá-los e circunscrevê-los; proponho o seguinte esquema: chamarei infância ao tempo em que o narrador era criança, seus pais estavam vivos, Santiago servia-lhe como criado e os episódios relatados enchiam a casa da Gávea de vida ativa; passado-recente - tempo intermediário, datado de 1992, quando o narrador, já então adulto e cineasta, tentou, sem sucesso, levar a cabo a ideia que dá mote ao filme; e presente, ano de 2005, quando o diretor retoma o projeto e a narração de fato se torna experiência compartilhada com o espectador. 0 primeiro está presente no filme apenas pelas reminiscências das palavras da voz-off, salvo pela exibição breve de uma filmagem particular da família de Santiago, à qual já me referi. Enquanto ouve-se no relato do narrador episódios da infância, recheados de personagens e enfeitados de experiências a serem partilhadas, os planos visuais dão o contraste: os corredores vazios da casa e os móveis cobertos por panos - que remetem ao passado-recente, quando essas filmagens foram realizadas - atestam o perecimento do tempo anterior; à riqueza de casos daquele tempo mais remoto, opõe-se o vazio humano de 1992. A infância tem como locus a casa da Gávea, onde os dois personagens conviveram e experimentaram o que agora é relembrado. 0 passado-recente está espacialmente descontínuo; as filmagens foram feitas em três locais distintos: na mesma casa da Gávea, agora vazia, no apartamento onde, então, vivia Santiago e algumas cenas em estúdio, esse antilugar cuja existência só é válida no interior do microcosmo ficcional. Ao presente, entretanto, não é possível associar espaço físico algum, pois ele habita o filme pela voz do narrador e pela edição das trilhas sonoras e visuais; é um espectro diluído e sem cores que ronda e conduz a narrativa; para capturá-lo, é preciso olhar para a forma discursiva como são articulados os elementos fílmicos, como são construídos os personagens e os tempos e, principalmente, de quais sujeitos emanam e como são distribuídas - se de fato o são - as vozes que compõem a obra.

Por todo o filme, os espectadores assistem à polarização de dois caracteres sociais: João Salles, identificado como burguês, homem de posse, o dono da câmera e antigo filho do proprietário da casa onde trabalhava Santiago, e este último, posicionado no outro extremo, empregado e personagem submetido às ordens do diretor. A caracterização de "Joãozinho" - como o chama Santiago - como homem crescido no berço caro da burguesia começa nos planos da casa vazia, grande e portentosa. Outras pistas ao longo do filme reafirmam, sem deixar dúvida, esse olimpo de classe com o qual o personagem-narrador é abençoado. Já não é comum uma família 
carioca ser servida por um empregado sob o ostentoso título de mordomo, que é atribuído a Santiago, revelando uma marca de status; ademais, aos dois minutos e cinquenta segundos, o narrador diz que a casa contava com muitos empregados, era palco de jantares de negócios, bailes e grandes festas.

A voz do narrador foi gravada por Fernando Moreira Salles, irmão do diretor João Salles, conforme podemos ler nos créditos finais. No entanto, a todo momento a voz pronuncia-se na primeira pessoa, referindo-se ao personagem-diretor como eu. A voz-off emana de um personagem ficcionalizado, algo como um eu-lírico que, não obstante represente uma pessoa real, João Salles, tem sua existência tecida e desenhada no interior do quadro fílmico. A voz do narrador atua como elemento orientador dos fatos expostos, estruturador e diretor do filme, sendo dela que procede a sequência dos conteúdos, o fluxo dos planos e da trilha sonora. No entanto, por um procedimento inusitado, a voz que conduz Santiago aponta brechas na sua condição de autoridade, acusa-se como manipuladora e incita o espectador a procurar, nas entrelinhas de suas incertezas, os instrumentos retóricos com que o cineasta procura orientar o sentido do olhar do receptor. 0 narrador, num espírito incontido de autoacusação, lança o espectador num exercício de questionamento que coloca em cheque a autenticidade das vozes do cineasta, narrador e personagem, articuladas no filme. Até que ponto é possível entrar em contato com Santiago, ver seu modo de ser, ouvir as palavras que, supostamente, expressam seus sentimentos e opiniões? 0 personagem-título construído no filme corresponde ao eu espontâneo de Santiago? Ou tudo não passa de um diretor-manipulador usando a imagem e a voz de outro para falar de si, tão-somente de si, projetando no seu personagem sua própria visão de mundo?

\section{A casa e a câmera: em tempo de compartilhar}

Santiago construía uma enciclopédia dos homens e das famílias mais notáveis da história. Ao longo de 50 anos, despendeu um trabalho minucioso de pesquisa e escrita que, certamente já sabia ele, em nada daria, não encontraria nenhum proveito, nenhum leitor; seria tão-só um amontoado de papel ornamentando, com orgulho solitário, a mobília de sua sala. Sua empreitada - dispendiosa, já que produziu mais de duas mil páginas escritas - não tem outra razão de ser que o gozo de um capricho que se encerra nele mesmo. Uma construção que exige o empenho obsessivo de braços em esforço, mas cujo fim é o próprio trabalho de construção. E o espírito 
artesanal de Santiago vai além da pesquisa e da escrita: após findas, as páginas são cuidadosamente agrupadas em ordem cronológica (em relação ao assunto sobre $o$ qual falam) e amarradas em blocos, por um laço vermelho que Santiago mandava vir de Paris. 0 mesmo capricho do personagem, vemos nos cômodos da casa, tomados em planos de conjunto, em que a mobília é cuidadosamente disposta, compondo um cenário esteticamente calculado ainda que materialmente pobre. Na cozinha, contamos ao menos seis panelas penduradas em ganchos suspensos em um estreito espaço entre o fogão e um armário; suas latarias amassadas nos lembram a condição economicamente simples de Santiago, no instante das filmagens; elas, mais do que servir à alimentação do único morador da casa - seis panelas de tamanho e formato semelhantes não são muitas para uma só pessoa? -, são elementos manuseados, como esculturas, na construção de um espírito que o ambiente conota por todos os cantos. As panelas de Santiago, ao fundo do quadro, falam de sua personalidade e de seus caprichos, de sua obsessão em organizar e fazer de coisas banais meios de expressão, nos quais ele imprime um estilo de vida.

O narrador relembra um episódio passado na infância, que me parece, pela força poética, o auge da caracterização do personagem-objeto e que se dá logo aos 10 minutos:

\footnotetext{
Me lembro que, certo dia, meus pais disseram a Santiago que iam jantar fora, que ele podia fechar a casa e se recolher. Eu era menino, dormia cedo. Por volta da meia-noite, acordei com uma música. Percebi que alguém tocava o piano que ficava no início dessa galeria; que, agora me dou conta, talvez devesse ter filmado à noite. Me levantei nas pontas dos pés e fui até lá. Quando cheguei no salão, vi Santiago. Ele vestia o fraque que usava nos dias de grandes festas. Não me espantei com a música - não era raro ver Santiago ao piano - me espantei com o fraque. Perguntei: "Por que essa roupa, Santiago?" Ele me respondeu apenas: "Porque é Beethoven, meu filho!".
}

As imagens não fazem outra coisa senão contra-ilustrar a narração, com planos da casa desabitada, relembrando o contraste entre o vazio humano das fotografias do filme, no seu preto-e-branco melancólico, e a vida pulsante rememorada nos relatos. Mas o que me interessa na narração transcrita é a caracterização com que o narrador vai formatando seu personagem. Há de se convir que vestir um fraque, usado apenas em condições especiais, para usufruí-lo sozinho, no escuro da noite, parece contrário ao que é socialmente convencionalizado como a função das roupas: elas são usadas para serem vistas e, se possível, apreciadas. Santiago constrói, segundo o narrador, uma relação entre o compositor, cuja música ele executa, e a 
roupa que deve usar, mesmo desamparado de qualquer plateia ou apreciador. Um fraque usado em solitário, no escuro, é um capricho satisfeito em si mesmo, sem conduzir a fins úteis ou a ganhos individuais; é como uma enciclopédia que nunca vai ser lida, senão pelo seu próprio autor, ou como filmagens e edições que nunca viraram filme, jamias sendo utilizadas ou exibidas, ou ainda como um filme totalmente fracassado em público.

Minuto 66. Planos de detalhe dos escritos de Santiago cobrem todo o enquadramento. Alguns trechos vão sendo lidos pela voz do diretor-narrador. São pequenas narrativas sobre pessoas que viveram em tempos distantes, famosas o suficiente para terem o nome numa enciclopédia extensa, mas não a ponto de serem populares ou identificadas com alguma familiaridade pelo espectador. Os escritos de Santiago parecem não fazer parte do mundo moderno. Estão sempre transportados para um tempo remoto, quando as histórias pessoais ainda eram passíveis de serem narradas, quando a experiência vivida ainda não estava desmontada e guardada num baú psicológico, cujos pedaços só estão acessíveis ao indivíduo introspectivo. No mundo resgatado por Santiago, a experiência ainda tem alguma partilha coletiva, de modo que a biografia de um homem notável da nobreza francesa de séculos atrás seja capaz de despertar interesse. 0 fio da história que religa um passado remoto ao presente ainda não estava fissurado. Bastava que alguma entidade subjetiva, munida de um pouco de sabedoria e paciência, se propusesse a recuperar esse vínculo, para que as temporalidades se intercomunicassem.

No universo particular de Santiago a construção, o artifício e o ornamento estão onipresentes, a fim de, com eles, incutir algum sentido em objetos que, se tomados em sua suposta voz própria, estariam silenciosos e esteticamente vazios. 0 filme Santiago é fundido ao personagem Santiago; no microcosmo sublime de um e outro, tudo é construção! Qualquer aparente despropósito foi planejado; os detalhes mais marginais carregam-se de significado e intenção estética. Tanto o espírito sublime do filme, como o ar de elevação que Santiago, o personagem, inspira, resultam da costura discursiva articulada por uma inteligência criadora que mobiliza os recursos ao seu alcance, com o propósito de dar expressão àquilo que sozinho não o teria.

0 minuto 40 exacerba o que já era sugerido. Conforme nos vão sendo mostradas cenas das filmagens de 1992, o narrador comenta o processo construtivo que se passava por detrás delas. Mostra um plano aberto da piscina da casa da Gávea; avisa que vários planos iguais a esse foram tomados repetidamente até que fosse 
obtido um, capaz de potencializar aquilo que se quer expressar. Em seguida, após dois cortes, uma folha cai à direita do quadro, o que é comentado pela voz-off. Depois de outro corte, num plano semelhante ao anterior, o narrador pergunta: "Mas quais são as chances de, logo no take seguinte, outra folha cair bem no meio da piscina?" E, simultaneamente, a imagem faz cumprir a hipótese anunciada. Em seguida, vê-se uma terceira folha caindo no meio da piscina, e o narrador questiona se o leve movimento que vemos na água fora causado pelo vento, ou por uma mão deslocada do enquadramento e movida por algum membro da produção, a fim de causar o efeito desejado - e seria a mesma mão que jogara a folha na água, simulando a referida coincidência?

Passa-se aos takes dos cômodos desabitados da casa. Os móveis estão cobertos pela colcha que indica o abandono, os chãos vastos e desocupados, as cortinas pesadas e imóveis, os quadros de retrato quase invisíveis pela falta de luz... Com alguns cortes, mas mantendo a câmera no mesmo ponto, o narrador nos faz ver e ouvir que os móveis eram alterados segundo os objetivos da filmagem. A mão construtura do artista parece contaminar tudo que a princípio tivesse algum traço de espontaneidade. Não fica nada livre da manipulação guiada pelos propósitos de construção dos sentidos.

Entre os minutos 41 e 54, são postas em sequência inúmeras cenas contendo as mais bruscas intervenções de João Salles nas falas do seu personagem, Santiago, que se revela não apenas um entrevistado, mas um ator conduzido por um diretor interessado em perseguir uma performance capaz de dar voz à sua ânsia de expressão. Os planos estão no mesmo tom dos que já vimos até então, mostrando Santiago, em plano geral, apertado dentro de um dos minúsculos cômodos de seu apartamento, normalmente sentado, declamando seus depoimentos como poesias decoradas. Noutras vezes já havíamos ouvido a voz do personagem-diretor, que interceptava as falas do personagem-objeto para estimular questões. Agora, porém, essas intervenções são-nos apresentadas na forma de um imperativo que coage e condiciona, dirige, orienta e até oprime as falas e toda a performance do entrevistado, reduzido-o a não mais que um corpo e um nome emprestados à ação construtura da ficção, que serve quase despoticamente ao personagem-diretor. 0 cineasta faz mais do que instruir, ele ordena a Santiago como agir, às vezes até com sinais de impaciência e rispidez.

Dos minutos 63 a 65, temos todos os elementos que sugerem a construção de uma ficção. Vê-se o personagem, transvestido de ator, buscando o tempo certo para a ação, tentando relembrar a fala que lhe faltou à memória durante o último take de 
filmagem. Primeiro, Santiago discursa em tom poético sobre a vida, citando uma frase de Ingmar Bergman. Em seguida, após um corte, o personagem e a câmera estão no mesmo lugar, mas agora entre eles está a claquete. Santiago vai começar a falar; antes, olha para alguém fora de quadro, certamente o diretor, e pede algo como uma orientação ou permissão. Ouve-se a voz do personagem-diretor, que comanda o seu dirigido. Depois de um novo corte, a placa sobe e estala novamente, e Santiago, outra vez, declama a citação de Bergman; o personagem, porém, se atrapalha no meio da fala e emenda no fim uma frase que, fica sugerido, deveria ter dito no começo - como o ator que percebe ter "comido barriga" durante a performance e indica ao diretor que é preciso inciar uma nova tomada. Por fim, temos outra tentativa, cujo resultado fílmico parece satisfatório. Note-se: apenas este último take, numa obra sem a mesma pretensão autorreflexiva, seria o material aproveitado para fazer parte da composição final do filme, descartando todas as tomadas insatisfatórias anteriores.

O trabalho construtor do cineasta chega ao ponto de ser sugerido como fruto de decisões que beiram o arbitrário. Se Santiago, com seus nobres e suas castanholas, modela para si um mundo que funciona segundo seus caprichos e satisfaz a gratuidade de seus gostos, João Salles aprendeu com o antigo mordomo, e parece tecer um filme ao sabor das suas veleidades de artista e criador. Para isso, ele se aproveita da facilidade de ser o proprietário da câmera e estende seu capricho sobre o outro, cuja imagem está sob seu poder. 0 diretor orienta Santiago a falar sobre os arranjos de flores que ele ornamentava na casa da Gávea, e o narrador relembra: "Não sei porquê, mas pedi a Santiago que contasse isso em pé, olhando para a parede".

Ao se ouvir a voz imperativa do diretor sobre o personagem, imediatamente leva-se o espectador a imaginar o garoto Joãozinho, sob o mimo dos pais, dando ordens ao empregado, adulto culto, cujos prazeres estão reduzidos, pela desigualdade econômica, ao gozo da submissão. 0 desnível de poder entre as vozes de Santiago e de João Salles está alicerçado em estruturas anteriores e fincadas na carne dos dois homens, que agora ficam frente à frente, um de cada lado da câmera.

Num dos momentos mais melancólicos do filme, dos minutos 72 a 74, o narrador lamenta seu desinteresse sobre um relato em que possivelmente falaria a voz do personagem Santiago, com alguma ponta de espontaneidade. "E, no fim, quando Santiago tentou me falar do que lhe era mais íntimo, eu não liguei a câmera". Uma tela preta evidencia visualmente o que acabou de ser dito: a câmera está desligada, 
certamente para poupar filme, preocupação que por mais de uma vez ouvimos na voz do diretor ao longo das suas intervenções; somente ruídos e vozes são ouvidas, o gravador de som continua ligado. Santiago, com um timbre inseguro na voz, pede docilmente ao cineasta que grave seu depoimento sobre uma história que nos fica desconhecida, algo sobre ele pertencer "a um núcleo de seres malditos". No entanto, Joãozinho não lhe dá atenção e rapidamente desqualifica a importância do relato para o filme.

A operação discursiva de João Salles faz despontar um efeito reverso, que remete o espectador ao que pode ter sido articulado como artifício na narrativa construída em 2005 - não mais apenas sobre o material bruto de 1992; isto é, as manipulações para as quais nossos olhos são despertados, não acusam somente o cineasta que filmou as conversas com Santiago, mas também o narrador, que emite juízos sobre o que vemos e que é, ficcionalmente, a mesma pessoa que compôs o discurso audiovisual do filme. O narrador, tão desconfiado do seu projeto de 1992, parece possuir, a um primeiro olhar, a mais honesta das vozes; porém o vírus da desconfiança, com o qual ele contagia, invoca uma suspeição que se volta contra ele próprio. Pergunta-se: teria mesmo o cineasta de 1992 desligado a câmera naquele breve momento em que Santiago começou a falar sobre seu vínculo com o tal "núcleo de seres malditos" e mantido ativo o gravador de som? Ou teria sido uma artimanha implantada pelo cineasta de 2005 que, foragido em sua ilha de edição, deixa a tela escura a fim de inventar uma situação sobre as filmagens, que caísse bem para o que pretendia expressar? 0 recurso de deixar a tela preta e manter rodando a trilha sonora é usado inúmeras vezes ao longo do filme; na maioria delas, certamente estaria justificado pelo corte necessário a toda câmera de filmar não digital, imposto pela troca do negativo. Entretanto, as telas pretas abundam pelo filme para além dessa necessidade técnica e material; algumas vezes construindo transições, outras simplesmente para deixar que a voz do personagem ou do narrador não sofra interferência de alguma imagem. Nota-se, sem equívoco, que muitas vezes o escurecimento total do plano visual responde a uma opção estética. No minuto 17, por exemplo, durante alguns segundos ouve-se $O$ Barbeiro de Sevilha no escuro. 0 filme faz brotar no espectador a suspeita de que possivelmente o "fade out" dos minutos 72 a 74, em vez de ser resultante do desligamento da câmera e do desprezo de João Salles pelo comentário que Santiago tanto queria fazer constar naquilo que acredita- 
va ser sua cinebiografia, foi manejado pela edição de 2005, por intuitos expressivos ${ }^{2}$. O espectador é instigado a questionar se, possivelmente, tudo não passou de mais uma manipulação do diretor sobre os recursos cinematográficos a seu alcance, na pretensão de obter uma sequência que funcionasse como argumento audiovisual à seguinte tese: num documentário, assim como na vida, produzimos incessantes artifícios segundo nossos interesses, como solução incerta, para dar às coisas o sentido que elas por si só não teriam.

Não somente existe um conflito entre elementos distintos articulados na composição do discurso tecido na obra - entre o narrador que fala do alto do ano de 2005 e o diretor que entrevistava Santiago em 1992 -, como há também, mais ao fundo da fossa que o filme escava, crises internas a um mesmo elemento: a voz-off do narrador, além de destrinchar o modus operandi do projeto de 1992, chega ao ponto de lançar uma crítica quase desconcertante sobre si mesma, provocando o espectador a tomar consciência dos mecanismos através dos quais ele entra em relação com o filme a que assiste. É sabido que a assimetria de poder entre o diretor e o personagem dificulta a inclusão deste último, no filme, como um sujeito com voz ativa e produtor de discurso, de modo a parecer impossível falar-se em um documentário polifônico. No entanto, as fissuras vistas dentro da única voz que nos fala implodem a continuidade e a coesão que ela poderia ter, e assim, em meio a esses destroços que se dispersam, reergue-se uma polifonia formada, não pela junção de vários sujeitos interlocutores, mas pelo dilaceramento de um único, fragmentado em muitas vozes que discutem num mesmo dialeto.

A mobilização de múltiplos recursos expressivos do documentário - como a exposição, a reflexão, a problematização da participação do diretor no processo de filmagem - e a tripartição do tempo narrativo realizadas no filme, fazendo-o assemelhar-se a um torneio confuso de linguagens, não propõem a instauração de um novo paradigma discursivo, mas, antes, afirmam que nenhum padrão de linguagem

\footnotetext{
${ }^{2}$ Vale notar que não se propõe neste artigo qualquer questionamento acerca do que de fato aconteceu no set de filmagens; em outras palavras, pouco importa para o raciocínio aqui desenvolvido a informação se a câmera teria mesmo sido desligada ou não pelo diretor. 0 modo como, e o momento em que, o problema do desligamento da câmera é enunciado no filme deixa ao receptor a sugestão de que um episódio aparentemente espontâneo poderia ser resultado de uma manipulação que lhe impõe um direcionamento expressivo, de modo que esse episódio, a princípio fortuito, passe a carregar sentido dentro de um discurso e seja proveniente de uma possível intenção autoral. Dessa maneira, o filme não chega a romper com um pacto firmado com o espectador, mas propõe um instante de dúvida que chama a atenção para a existência e os limites deste pacto discursivo. Trata-se de levar para o nível do efeito estético experimentado pelo receptor a forma da desconfiança diante de tudo o que pareça espontâneo ou natural.
} 
organizado e coerente é expressivamente potente para expressar o dilaceramento da experiência que dá insumo à memória e tutano ao presente, pois não se pode expressar uma percepção fragmentada em um discurso que se queira contínuo. Os recursos inter e autoconflitantes articulados no filme procuram faiscar ambiguidades, não no propósito de alcançar a totalidade da expressão através da ampliação dos sentidos artísticos, mas, sim, para nos comunicar sobre o modo incerto e instável como o cineasta percebe sua relação com o mundo.

A autoridade do diretor das entrevistas de 1992 sobre o personagem pobre e velho, do menino rico sobre o mordomo culto e cheio de ensinamentos, e a autoridade do cineasta de 2005 sobre o projeto herdado de treze anos antes, são, ao mesmo tempo, recobertas por uma afetividade e uma sensação tão profunda de dependência de um pelo outro, que não permitem ao homem João Salles formar qualquer fio de percepção contínuo ou coerente. 0 filho do patrão e o mordomo, na relação pessoal que travaram em vida, compartilharam uma experiência a um tal ponto ambígua lavrada pelo trabalho que os tornava opostos e aquecida pela mútua admiração que os reaproximava - que nenhuma linguagem previamente ordenada ou coerência artificialmente forjada teriam potencial para expressar. 0 dilaceramento da linguagem é a forma que expressa o dilaceramento da percepção, com suas contrariedades, incertezas e irresoluções.

Aos 8 minutos de filme, o narrador anuncia a "única sequência que sobrou da montagem de 1992". A montagem, então, é mostrada em seu formato bruto, exibindo inclusive o cronômetro que seria excluído após a finalização. Com esse recurso, o espectador é transportado para dentro da ilha de edição, onde pode fazer contato com as carcaças de um projeto naufragado. É notável, na montagem original, a livre colagem feita pelo editor, interrompendo frequentemente a trilha visual e mostrando, enquanto Santiago fala, planos ao gosto do diretor, inserindo, inclusive, as tomadas feitas em estúdio. Por outro lado, a edição assistida ao longo do filme deixa ver uma tentativa angustiada de dar a imagem de Santiago ao próprio Santiago; mostra-o enquanto ele fala e procura respeitar a continuidade dos seus depoimentos. É como se João Salles, em 2005, procurasse amarguradamente respeitar as palavras e os gestos corporais que seu ex-empregado descrevia ao falar, como se quisesse a qualquer custo reequilibrar uma desigualdade opressiva de poder que data de há muito tempo e é causada por razões que vão muito além do que pode fazer um filme documentário.

Enquanto Joãozinho brincava de mordomo equilibrando bandejas ao lado da piscina e sua família era servida por um empregado cheio dos melindres da alta clas- 
se, um serviçal que, embora serviçal, se identificava com a antiga nobreza de Florença e se deleitava imaginando-se um Modigliani ou um Cèzanne; enquanto ambos estavam cingidos pela curva arrasadora da posição econômica, alguma coisa os coabitava, um mesmo barro humano os tornava comuns entre si. Nem o dono da casa, tampouco o empregado, são sujeitos soltos, flutuantes num suposto vazio de orientações que permitiria a cada qual criar, a partir do nada, em pleno exercício de liberdade, o seu modo individual e subjetivo de ver e lidar com o mundo. Ambos se reencontram como seres culturais, interligados numa mesma cosmologia de verdades e possibilidades, enredados em um mesmo tecido, retalhado, de percepção de mundo.

Nesse sentido, retorna-se às dúvidas. De quem é essa voz, dilacerada, que a custo se equilibra sobre a ossatura cambaleante de uma linguagem em ruínas? A câmera de João Salles teria sido capaz de devolver a Santiago alguma ponta, ainda que mínima, de sua subjetividade e deixá-lo tomar a palavra? Enfim, quem fala no filme é Santiago? Quem fala é João, e tão-somente João? Mas qual deles, o cineasta que alçou o projeto em 1992, encantado com o sonho do "cinema direto"? Ou o homem mais maduro e amargurado que decidiu em 2005 enfrentar a brutalidade do material passado? Ou, ainda, quem fala é a casa da Gávea, grande o suficiente para abrigar tantas contrariedades, cujas paredes encerravam o mordomo no quarto dos fundos, mas lhe serviam de única plateia quando ele sentava a tocar piano, sozinho, noite a fora?

Há uma teia de englobamento que sequestra a visão de mundo do empregado e a promove fundida à visão de mundo do proprietário - seja de uma casa, seja de uma câmera. 0 interesse de João por Santiago e a curiosidade do mordomo pela vida de luxo e pela nobreza - que, em sua vida, fora representada pela família Salles são o dispositivo transcendente que abre a fina brecha em que torna-se possível ao indivíduo olhar para fora do círculo restrito em que está inscrito e fixado pela sua condição social, ainda que a visão, do lado de fora, permaneça translúcida e turvada: o homem rico busca atiçar sua empatia pelo homem pobre, tentando promover um reencontro tornado impossível pela demarcação dos espaços desenhada pelo capitalismo. Se a posse da câmera é indicativo irrefutável de poder - assim como noutro tempo o foi a posse da casa -, o cineasta deve dar ao outro um espaço em sua lente, a fim de desmanchar a hierarquia que os torna distintos e recuperar, assim, a proximidade perdida - tal qual o patrão buscava simpatizar com o empregado convidando-o para compartilhar alguns instantes da festa ou da piscina. Mas infelizmente o cineasta e o proprietário só conseguem, na melhor das hipóteses, abrandar por poucos 
instantes a ruptura levantada pela desigualdade; basta deixar a câmera ligada por mais alguns minutos para que vejamos aquilo que se escondia fora do quadro: a submissão incontornável que marca a relação entre o diretor e o personagem ou o patrão e o empregado.

O discurso montado por João Moreira Salles em Santiago tenta uma desconstrução autorreflexiva das possibilidades de expressão a fim de apontar a incapacidade do sujeito em erigir uma concepção plena e contínua de mundo, frente à ruptura que subtrai o outro, este ser fundamental na formação de qualquer identidade. A percepção do homem-cineasta se dilacera quando a supressão da alteridade impõe-lhe uma lacuna violenta. Nesse sentido, tanto faz dizer que a voz que geme no filme é a de João ou a de Santiago, já que ambos compartilham a mesma fala entrecortada pelo silêncio da estupefação sentida pelo sujeito ao tomar ciência de sua impotência frente o curso da tragédia social que vê ao seu redor... e essa tragédia social, podemos dizer, transforma-se em tragédia cognitiva, caos epistêmico, esfacelamento perceptivo, tornada visível e material nas tensões do discurso fílmico.

Aos 46 minutos, o diretor pede que Santiago fale sobre sua memória, questionando se ele "se espanta" por ainda preservar viva tantas lembranças de um passado distante, habilidade certamente não muito comum em um senhor de 80 anos. Diante de uma resposta negativa do personagem, o entrevistador refaz a indagação, obtendo um novo "não". No entanto, o diretor - de quem apenas ouvimos a voz, baixa mas poderosa - permanece insatisfeito e reformula pela terceira vez a pergunta, substituindo o termo "espanta" por "surpreende", o que nos deixa entrever seu interesse fixo em obter do entrevistado uma resposta positiva, pois certamente ele a julgava mais funcional e expressiva para os propósitos do filme. Santiago, ao ouvir novamente a mesma pergunta, vestida em palavras novas, exibe uma insegurança quase infantil, que mais parece clamar por piedade e apontar a própria culpa, como quem percebe não ter dado a resposta "certa", decepcionando, assim, a expectativa de seu ex-patrão e atual diretor. 0 espectador o vê colocando as mãos ao ouvido para escutar melhor a inquirição que lhe é dirigida e entender as instruções que se escondem por detrás dela; por fim, ele completa com um entusiasmado “sim, me surpreende" e atribui sua tão detalhada memória a um prêmio da Divina Providência ${ }^{3}$.

\footnotetext{
${ }^{3}$ Faz parte do conhecimento popular a ideia de que há em toda pergunta a própria resposta. Embora essa afirmação seja exagerada, ela expressa um problema com o qual é comum nos depararmos no cotidiano e nos
} 
Entre o preto e o branco embevecidos da fotografia, conseguimos ver com clareza o que se passou: Santiago concorda com João, não com o que este diz, e sabe que está ali para isso. Conforme citei na nota anterior, Paulo Menezes identificou um problema análogo no antológico cabra marcado para morrer (que ele faz questão de grafar assim mesmo, com inicial minúscula), de 1984. Porém, o caso citado do filme Santiago está enriquecido por particularidades que me instigam a direcionar a interpretação para um caminho diverso daquele trilhado por Paulo Menezes na análise de cabra. Ao notarmos que Santiago preocupa-se menos em avaliar o conteúdo da pergunta de João, do que a intenção dele (isto é, concordar com o diretor, independente do que ele diga, pressionado pelo desnível hierárquico), percebemos um rastro de mútuo interesse humano entre eles. A intenção de Santiago desracionaliza-se: ela abre mão de um contato confiável com o mundo objetivo, em que o conteúdo da mensagem pudesse ser julgado como verdade ou mentira, a partir de uma interpretação subjetiva, sua. 0 que se esperava "burguesmente" de Santiago era a capacidade de afirmar sua subjetividade, superando a situação socialmente perversa que o desfavorece: vê-lo como guerreiro persistente manifestando-se espontâneamente, julgando a pergunta de João com critérios próprios. Porém, diante da frustração dessa expectativa, confirma-se a supremacia da estrutura social sobre o indivíduo; o que se vê é o sujeito abafado e oprimido, resignado a reproduzir um esquema de desigualdade previamente desenhado; o contato entre dois seres humanos está, portanto, irrevogavelmente subordinado à condição de classe e ao papel de cada um diante dos artifícios do poder.

Entretanto, opondo-me a essa interpretação, pergunto: qual situação expressaria mais contundentemente o isolamento do sujeito e sua perda de contato com o mundo exterior? Um diálogo, em que cada interlocutor procura orientar sua interlocução a partir de um juízo sobre o quanto há de verdade naquilo que ouve e diz (isto é, mais preocupado com o conteúdo da mensagem? Ou quando a intenção, em cada fala, leva em conta a expectativa do outro e procura estabelecer um contato diretamente com ela, o que pode implicar, muitas vezes, o desprezo pelo conteúdo da

documentários, quando, numa circunstância não raro ingênua, o entrevistador e o filme "acreditam" extrair do entrevistado a mais espontânea das respostas, enquanto sabemos que, na estrutura da pergunta e dependendo da relação de poder entre quem pergunta e quem responde, uma ou outra resposta pode estar já previamente incitada. Este problema foi comentado por Paulo Menezes (1994, p. 120-122). 
mensagem? Certamente, no primeiro caso, é nitido que Santiago, diante da pergunta de João, perde o senso da objetividade e nega, assim, sua autonomia subjetiva - a capacidade de decidir e expressar com liberdade se a sua memória o surpreende ou não -, quando se olha para o filme com a sensibilidade que ele solicita do espectador, compreende-se, da atitude de Santiago, o resgate de uma intersubjetividade que posiciona os dois sujeitos interlocutores em uma relação humanamente significativa, ainda que esta posição indique uma postura submissa. Se é vista, com todas as cores, a submissão inconteste de Santiago, sente-se, por outro lado, o adensamento de um contato humano, em que vale mais a pessoa do interlocutor do que a mensagem que este emite, um religamento que é simultaneamente afetivo e hierárquico. 0 mesmo capitalismo que faz da hierarquia a argamassa das relações humanas e fixa nelas uma substância irreparável de submissão e dominação, torna a todos, ao mesmo tempo, aversos e repulsivos a qualquer forma de submissão que possa ser fotografada e exibida à vista, já que a imagem do homem submisso contraria a imagem do homem produtivo e dotado de domínio sobre o mundo exterior. Os cientistas sociais do século XX, preocupados em identificar e acusar as armas da opressão, interpretaram as diversas formas de submissão como indicativo triste e criticável da resignação do oprimido ao opressor. É preciso enunciar que - não somente na vida sexual - a submissão, essa deliciosa invenção do espírito humano, é forma de gozar em um meio adverso. Economicamente impedido de gozar como nobre, Santiago goza como empregado de uma família de burgueses - o que seguramente não é a mesma coisa, mas pode acalmar um irrequieto capricho humano. Submissão experimentada como prazer costuma ser definida por masoquismo; o masoquismo é o hedonismo do fraco... e os fracos somos muitos, senão todos. 0 personagem concorda com o diretor da mesma forma que, quando somos convidados a jantar na casa de um amigo ou parente, elogiamos o tempero da comida, qualquer que seja o prato que nos deem para comer - um misto de etiqueta e afeto, que, se por um lado pode estar negando a "verdadeira" reação do nosso paladar, por outro, é a afirmação subjetiva de um desejo mais profundo: o de não desagradar o anfitrião, pois ele, além de nosso amigo ou parente, é o dono da casa onde estamos comendo. Santiago e Joãozinho - opostos, primeiro, pelas posições de mordomo e do filho do patrão, depois, pelas funções que ocupam de cada lado da câmera - se reencontram em uma relação densa em significado humano, pela qual se estende um fio de alteridade, frágil mas ainda assim capaz de interligar diretamente um sujeito ao outro sujeito. Just a cruel remedy! - diz a epígrafe, de Beth Gibbons. 


\section{A conclusão impossível}

Note-se o modo como o narrador insere Santiago na narração, logo aos 3 minutos. Conta que ele, João, e seus irmãos, quando crianças, gostavam de brincar fingindo-se de mordomos, “[...] quem punha a bandeja na minha mão e me ensinava a equilibrá-la sem derrubar os copos era Santiago, o mordomo da casa". Santiago vivia seu teatro introspectivo na experiência da imaginação em que transformava a casa da Gávea num castelo de Provença, os eventos de boxe em lutas de gladiadores. Do mesmo modo, os meninos ricos desciam pirâmide abaixo e tomavam o empregado como modelo para imitação nas brincadeiras ao lado da piscina. Doce e infantil desejo de conhecer o que é estranho; deleite de brincar de ser o outro! Uma curiosidade do menino pelo homem que não faz parte da família mas dedica a vida a servi-la; curiosidade que o levaria, quando adulto, a fazer do ex-empregado o personagem de seu filme. Se Santiago invadia, devido a seu trabalho de mordomo, a vida pessoal da família Salles, agora é o próprio Joãozinho que penetra, impulsionado pelo trabalho de cineasta, na vida privada de Santiago. É como um acerto de contas, que infelizmente - e tragicamente - jamais se concluirá, mas que, ao menos, levou os dois homens a sujarem juntos as mãos do mesmo barro comum de que são feitos.

A história de Francesca da Rímini, a personagem preferida de Santiago em seus escritos, segundo o narrador, é esclarecedora: amante da beleza e obrigada a casar-se com um homem incrivelmente feio e deformado, ela se entrega em adultério ao cunhado, Paolo Malatesta, este, sim, belo e atraente. Um dia, o esposo os surpreende e atravessa com a espada a mulher e o amante. A beleza (incorporada por Francesca e Paolo) é punida pela feiura (incorporada pelo marido traído), já que esta lhe é mais forte devido a uma hierarquia de gênero e moral. Dante Alighieri se compadece dos amantes e os salva do esquecimento tornando-os personagens da Divina Comédia. Entretanto, a ideia de adultério era inevitavelmente incômoda para os costumes da época, de modo que, apesar dos esforços de Dante, não seria possível ao poeta levar longe essa absolvição post-morten e transformá-la em algo como uma elegia aos amantes. Só lhes resta um lugar incômodo nas páginas do inferno. João Salles mira sua câmera sobre Santiago, salvando-o do anonimato, condição esta que é, talvez, um tanto desmerecida para um homem de sua sensibilidade e cultura. Já que são as estruturas que descem às ruas ${ }^{4}$ e somente elas poderiam incitar alguma mudança na

\footnotetext{
${ }^{4}$ Essa afirmação é o oposto da frase "As estruturas não descem para a rua" que causou discórdia entre L. Goldmann e J. Lacan, arguidores da fala de Foucault em "O que é um autor?” (FouCAULT, 2006, p. 293 e 298).
} 
desigualdade que transpassa do círculo privado, vivido entre patrão e empregado, à tela exposta do cinema, disputada num jogo perverso por cineasta e personagem, só resta ao indivíduo João Moreira Salles usar essa mesma iniquidade e articulá-la no interior de seus abortos mentais, a fim de edificar alguma coisa - sempre incerta que torne, ao menos, mais serena e passageira a imagem insuportável da vida.

Lúcia Nagib apontou o papel da utopia nos filmes brasileiros. Outrora os cineastas diziam ver, na linha do horizonte, manchas se elevando sobre as águas, que seriam, talvez, a imagem da silhueta de um novo mundo, mais justo, que lá adiante adormecia esperando pelo dia em que se chegasse a ele. Na década de 1990, a intensificação do processo capitalista levantou uma quarta parede que intercepta o percurso do olhar do artista sonhador, pondo-se entre o homem que da areia olha o mar e o alto mar, cujas águas, agora, não vão muito além do banco de areia e terminam numa crista de rochas incruzáveis, onde não vemos senão o reflexo do mesmo lado de cá (NAGIB, 2006). Nos filmes apontados por Lúcia como representantes desse momento de desencanto - entre os quais ela destaca Cidade de Deus e O Invasor -, a derrocada do sonho da utopia é vivida sempre por personagens desgraçados pelas condições econômicas e sociais, esquartejados pela pobreza e desnutridos pela violência, que olham para o mundo mirando-o do alto do morro; e ainda que, por espírito subversivo, visitem o lado de baixo e entrem em contato com a grã-finagem - como o personagem Anísio, de $O$ Invasor -, não deixam de estar com a alma refugiada no barraco da favela, de onde assistem ao enferrujar-se das poucas rachaduras de céu ainda visíveis entre as fendas do zinco corroído. 0 caso de João Salles, o personagem angustiado de Santiago, é diverso e, certamente, mais incomum. Homem rico, livre, portanto, das mazelas explícitas do capitalismo, ele experimenta o fim da utopia como dilaceramento do sujeito, corte da expressão, fissura do contato humano, quase todo perdido. Na lente burguesa do narrador, assiste-se ao fogo cruzado do desejo subjetivo de expressar-se, que se inflama e insurge contra a percepção violentada. Ao invés do mar inundar a terra seca, como queria a profecia glauberiana, foi o sertão do oprimido que se espalhou por toda parte e chegou até à mansão da Gávea; pena! eu lá não brinco mais.

\section{Referências}

Foucault, M. (2006). “O que é um autor?”. In: . Ditos e Escritos III - Estética: literatura e pintura, música e cinema. Rio de Janeiro, Forense Universitária. 
Menezes, P. (1994). "A questão do sujeito herói em cabra marcado para morrer, filme de Eduardo Coutinho". Tempo Social, São Paulo, vol. 6, n. 1-2.

NagiB, L. (2006). A Utopia no Cinema Brasileiro: matrizes, nostalgia, distopias. São Paulo, Cosac Naify.

Recebido em setembro/2011

Aprovado em julho/2012 